\title{
Research on the Role of Media Supervision in Corporate Governance
}

\author{
Junwen Xue $\mathrm{e}^{1, \mathrm{a}^{*}}$ and Guoping Cheng ${ }^{1, \mathrm{~b}}$ \\ ${ }^{1}$ School of Management, Wuhan University of Technology, Wuhan, China \\ a15527315356@qq.com, bchenggp@whut.edu.cn
}

Keywords: Corporate governance; Media supervision; Governance effect; Corporate external governance; Professional manager

\begin{abstract}
Corporate governance is a hot research topic in recent years, the outbreak of Enron scandal has caused scholars to pay attention to the role of media supervision in corporate governance. This paper summarizes the views of scholars and affirmed the positive role of media supervision on Corporate Governance. Constructing the relationship model between media supervision and corporate governance to illustrate the role of media in corporate governance, and analyzes the path of media supervision to corporate governance and its influencing factors. Through the study, the author got the conclusion that the media supervision has a positive effect on corporate governance. Compared with western countries, because our manager market is not mature enough , some state-owned enterprises lack of effective supervision and punishment mechanism for the management, and the development of media industry is not mature enough, leading to the media supervision can't play the function of corporate governance. Therefore, the role of media supervision on corporate governance needs more attention from scholars, business operators and administrative agencies, so as to strengthen the effectiveness of corporate governance of media supervision.
\end{abstract}

\section{Introduction}

Since the 1980s, with the wave of mergers and the rise of institutional investors, the problem of corporate governance has been paid more and more attention by foreign scholars, and corporate governance has become a worldwide hot topic in the field of theory and practice. Entering the 1990s, with the scandal of famous foreign companies such as Enron, WorldCom, Xerox and some Chinese Listed companies are exposed, once again aroused people's reflection and attention to corporate governance issues.

Corporate governance is divided into external governance and internal governance, the internal governance mainly discusses the internal factors such as the relationship between company's board of directors/management and shareholders. External governance mechanism research, on the other hand, is mainly refers to the capital market competition mechanism and related laws and regulations of the legislation system of research, it makes main study on stakeholders such as creditors, investors and employees. But now, our country also is in economic and social transition, the legal system isn't consummate enough. Social networks, media and political regulations have become an important external governance mechanism. Whether the media has the role of corporate governance, the mechanism of its role and how to better play the role of corporate governance is the focus of this paper.

\section{Literature Review}

The Positive Effect of Media Supervision on Corporate Governance. Some scholars believe that media supervision has a positive effect on corporate governance, as an important substitute mechanism outside the law, media through pre supervision, in-depth investigation of the matter and constantly tracking reports, and it can effectively improve the corporate governance mechanism, and improve the probability of correct violations.

Scholars theoretically analyzes the influence of media supervision on the governance of listed 
companies, and through the study found that the media can effectively improve corporate governance [1]. Through the study they found that the more freedom of the media to disseminate information, the better the corporate governance environment provided by the stock market [2]. Foreign scholars summed up the positive effects of media reports on corporate governance in two areas: media reports lead to legal penalties and media reports affecting the reputation of managers [3] .

Many scholars in our country support the view that media supervision plays an active role in corporate governance, study from the following two aspects. On the one hand, from the perspective of information disclosure, the discovery of authoritative and independent media reports can guide the guidance of public opinion, and reduce the cost of access to information for investors, so that investors can identify their own interests in favor of the company and the formation of a correct investment philosophy; On the other hand, from the perspective of corporate governance, media coverage affects the reputation of managers through public opinion, it will not only affect the internal governance mechanism, but also affect the external governance mechanism [4] . Some scholars have found the media can spread a lot of public information and private information, and effective media coverage can promote the dissemination of information, and reflect the changes in the stock price, can make the optimal allocation of resources, and promote the development of the capital market [5].And media supervision will reduce the management of the company's earnings management, and this oversight role for the company's analysts also apply, and it Is proportional to the institutional investor shareholding [6]. There are scholars through empirical analysis find that with the increase in the number of media exposure, the probability of listed companies to correct violations will also increase. Confirmed that the media has a positive role in improving the level of corporate governance and protecting the interests of investors [7]. In another empirical study, in the selected sample of 96 listed companies, $60.42 \%$ of the company's corporate governance issues are in the Commission formally involved in the investigation before the media questioned and negative reports, according to the principle of cost-efficiency principle, negative media reports tend to choose the nature of the serious and large amount of corporate governance issues [8].

The Negative Effect of Media Supervision on the Company. There are also a few scholars think that the media cannot bring positive effect to corporate governance. Those scholars believes that due to the effect of the infinite amplification, so that the whole enterprise may be caused by one of the companies are reported to be implicated, and damage to the interests of capital investors [9]. Through the case study of Wuliangye company, and through the analysis of the situation of Wu LiangYe related transactions and the payment of cash dividends, found that the media supervision of Wuliangye has not been able to reduce the transfer of large shareholders of the company's assets[10].

Literature Review. To sum up, the media attention to the listed company is an indisputable fact, although there are a few scholars questioned the effectiveness of the media on corporate governance, that in the context of different systems and different legal governance mechanisms, the role of media supervision on corporate governance is uncertain. However, most researchers believe that media supervision can reduce the asymmetry of information in capital market, and improve the transparency of information of listed companies, and it plays an important role in improving the understanding level of the enterprise, media supervision has a great positive effect on corporate governance. Media supervision, as an important means of corporate governance, needs more attention from scholars, managers and policy makers.

\section{The Role of Media in Corporate Governance}

The role of media in corporate governance can be divided into two aspects: the role of media in society and the information asymmetry in corporate governance, as shown in Fig. 1. 


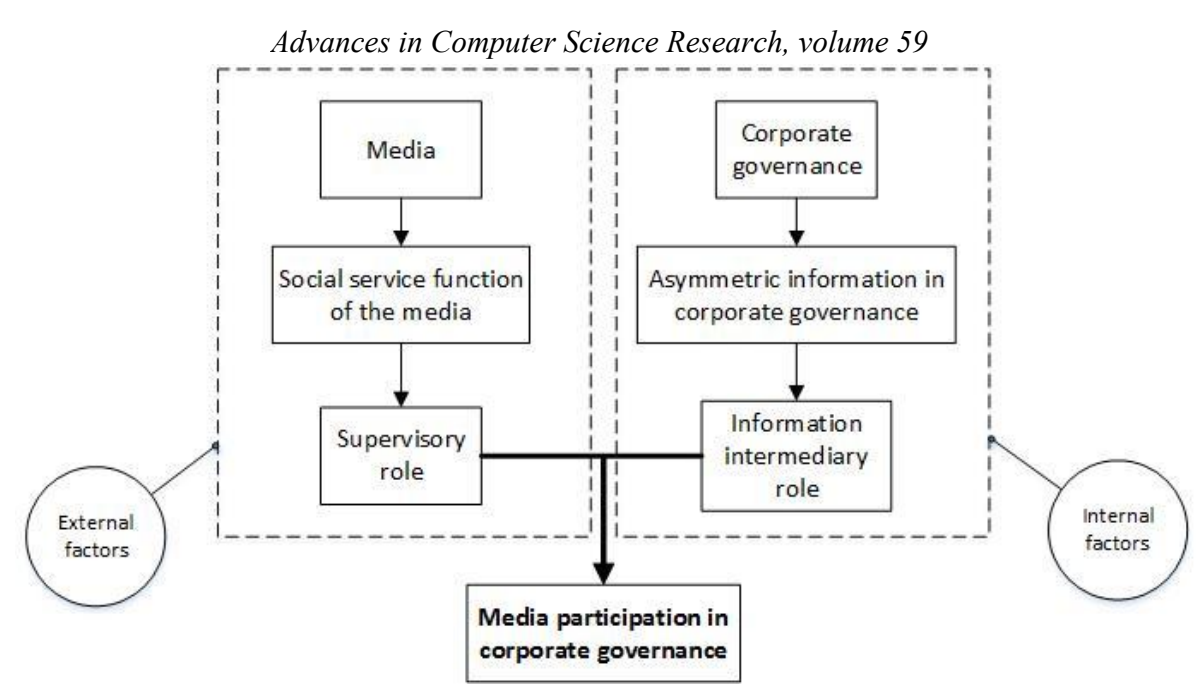

Figure1. Analysis of the relationship between media and corporate governance

Supervisory Role of the Media. One of the social service functions of the media is the supervision of the society, and the media coverage of the social phenomenon reflects the social service function of the media. Media refers to the mass media such as newspapers, magazines, radio, television, Internet and so on. The media function of social service requirements and media practitioners in news media must fulfill the social stability, the national security and public health law and ethics of public responsibility and social responsibility. The value judgment of the media can reflect the customs and culture of a country as well as the media's career sensitivity, it is important to alleviate social contradictions, promote social justice of power. With the development of the modern joint-stock company, the media participation in corporate governance has explained the social service function of the media. As between the company and the community, investor communication channels, media attention of enterprises continue to increase, making the enterprise management goal and the enterprise to fulfill the social responsibility more and more stakeholders especially the attention of the public.

Information Intermediary Role of Media. As an important medium of information in modern society, media is an effective way to solve the problem of asymmetric information [11]. The function of the information disclosure of the media exposes the information of the listed company to the stakeholders. The negative reports of the listed companies can improve the probability of the enterprises to correct the violations, media exposure in promoting enterprises to correct violations, to protect the interests of investors has shown a very positive role. On the one hand, the information of the government, the enterprise and the stakeholders are mostly processed and selectively transmitted through the media, they use the media to solve the problem of asymmetric market transactions, and reduce the cost of investor participation. Through the media in a timely and accurate and impartial reporting and disclosure of trading information in the process, the two sides in a fair market transaction status, to prevent the market information is not sufficient to judge mistakes, to protect investors' role. On the other hand, the media as a supervisor, in violation of the rules in market transactions and the existence of loopholes in the rules of disclosure, can guide the company to improve the internal system, ensure the efficient flow of information, so as to achieve the purpose of protecting the investors.

\section{The Path and Condition of Media Supervision on Corporate Governance}

The Path of Media Supervision in Corporate Governance. The role of media supervision in corporate governance has three paths: reputation, administration and investor behavior. As shown in Fig. 2. 


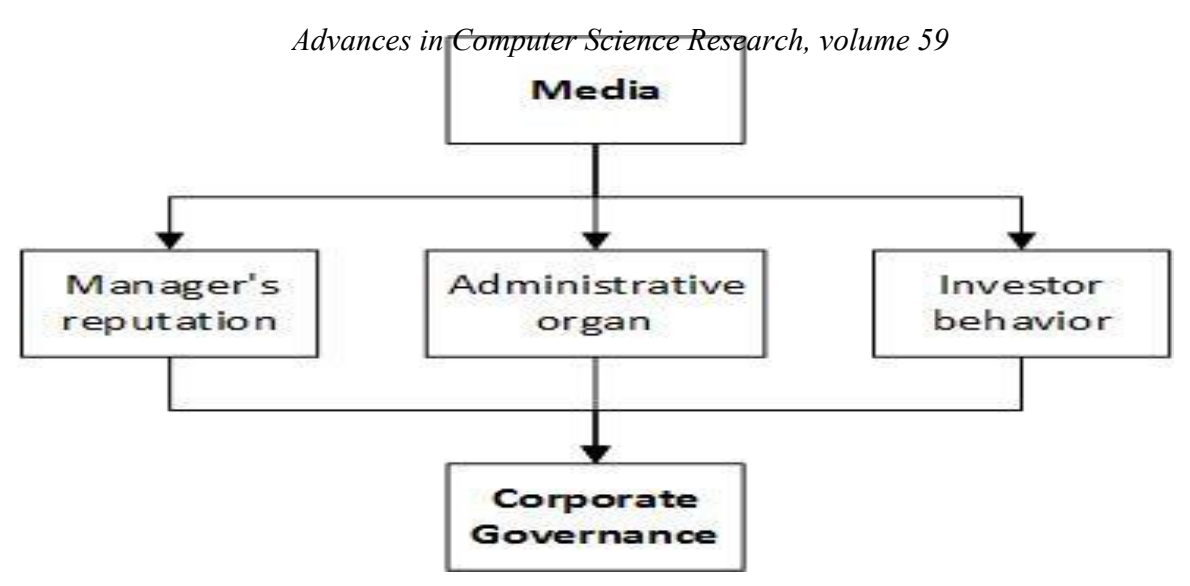

Figure 2. Three kinds of paths of media supervision influence corporate governance

(1) Reputation path. In the western mature manager market, managers will pxay more attention to their reputation on the basis of the salary and employment development in the future. In reality, the negative media coverage will hurt the manager's reputation to some extent, so the manager will take positive measures to deal with the media reports. But for China, which is in the stage of transition, China's state-owned equity is still in a larger proportion of ownership structure, due to the lack of effective supervision and punishment mechanism for the management of state-owned enterprises, the cost of moral hazard is very low. As a result, leading to the lack of competition in the management of the market and the pressure of unemployment, and not as mature as the western countries, the media's negative reports through the reputation of the path is difficult to play an effective role.

(2) Administrative path. Media coverage has a good disclosure function, exposure to the problem of corporate governance process, increasing the likelihood that the problem was found by the regulatory authorities. Negative media reports will prompt lawmakers, administrative officials and other politicians to amend the proposal and the implementation of the company law, help to improve corporate governance. In China, the media is caused by the concern of the administrative body, to enhance the administrative costs of illegal companies to play a corporate governance and to promote violations of the company to correct violations.

(3) Investor behavior path. The media information can effectively increase the quantity and quality of the information obtained by investors, thus reducing the information asymmetry in the investment process and the limitation of investors' limited cognition. Through the information disclosure and communication of the listed companies, the media influence the image of the listed companies in the public mind, it causes the change of the information environment of the capital market, and then affects the investment decision and the stock price change.

The Conditions of Media Supervision on Corporate Governance. If the media supervision wants to play the role of corporate governance, if and only if the private benefits obtained from the violation of the rules of corporate governance are less than the potential reputational costs and legal penalties, and business managers will really take action to correct violations, and vice versa, businesses and managers will maintain the status quo, continue to engage in irregularities [12]. As shown in the Eq.1:

$\mathrm{E}$ (Private benefits $)<\mathrm{E}($ Reputation cost $)+$ (Legal punishment $)=\sum p_{i} \times R C_{i}+\pi P$

Among them, $\mathrm{RC}_{\mathrm{i}}$ is the reputation cost caused by the behavior of the enterprise managers violating the corporate governance standards, which is criticized by the $\mathrm{i} ; \mathrm{p}_{\mathrm{i}}$ is the probability that the audience I accepts the media information and converts the information into their own beliefs; $\mathrm{P}$ is a penalty for breach of corporate governance guidelines; the probability of violation of $\pi$ is corporate governance standards act punishable by law. It is through the influence of $R_{i} 、 p_{i} 、 P$ and $\pi$ to play the role of corporate governance. Therefore, under the condition that the audience of the media influence as much as possible and the public values need to be consistent, the role of corporate governance of media can be more fully utilized. 


\section{The Factors that Influence the Role of Media Supervision in Corporate Governance}

The Credibility of the Media Itself. Only the information provided by the media is accurate and reliable, and to maintain its own impartiality in order to play a role in the supervision of corporate governance. The establishment of media credibility is mainly based on whether the information provided is reliable and accurate. An important source of information is the government, for example, the media directly or indirectly obtain the information the government requires the company to disclose. This information is the most reliable because it is not affected by selection. Journalists can also get information from managers and employees. However, such information is often filtered and selected by managers and employees, it is possible that the exchange of journalists in a certain condition. This information is often not accurate enough, in the long run may have a bad impact on the credibility of the media. Information may also come from a number of intermediaries. Such as accounting firms, stock and bond analysts. These sources may be more objective.After the establishment of credibility, the media play a supervisory role, but also mastered a powerful guide to public topics and public opinion oriented power.

Competitive Media Environment. In a competitive market, a media that agrees not to publish bad news is likely to lose the credibility of another media. Therefore, in a more competitive environment, the possibility of collusion between the media and the interests of the subject will be lower. In addition, the more dispersed the media, the company will be responsible for the interests of minority shareholders.

Media Ownership Structure. Some people think that information should be provided by the state-owned monopoly enterprise, because information is a public product, on the contrary some people think that the government is not completely benevolence, state monopoly media may distort and manipulate information, shelter the current government, democracy and market failure. At present, in the United States, the government regulation of the media is to relax, which leads to a media industry for government ownership is not all, but for the oligopoly; on the other hand is a media enterprise excessive pursuit of commercial interests, in collusion with the government and interest groups, ignored the occupation spirit more basic.

Legal Protection of Freedom of Speech in the Media. In the absence of government regulation and the lack of credit, it is necessary to guarantee the supervision of the media to the listed companies in order to exert the power of the media to strengthen the external governance of the company. But if there is a strict "libel law", for self-protection consciousness, the media will reduce the release of those who expose managers of bad behavior news, which will reduce the amount of information media, it will weaken the supervision function of media.

\section{Conclusions}

Through the summary of previous studies, we can conclude that media supervision plays a positive role in corporate governance. The media plays a supervisor and information intermediary role in corporate governance, reduce information asymmetry through its social service function, strengthen the attention of stakeholders, public and administrative departments on the management of the company, and urge companies to strengthen governance. The media plays a positive role in corporate governance by affecting the reputation of managers, attracting the attention of the executive authorities, and affecting the behavior of investors. However, some of the factors of the media itself will affect the effect of governance, because the development of China's media is in the initial stage, so we need to create external conditions to promote the development of the media. For example, moderately improve the independence of media coverage, while strengthening the self-discipline of the media; by strengthening the supervision of the media, so as to form an effective competition between the various media. In addition, it is necessary to establish a credit society, to strengthen people's attention to the reputation, and promote the formation of good social norms, and strengthen the positive role of media supervision on corporate governance. 


\section{References}

[1] Dyck A and Zingales L. The Corporate Governance Role of the Media. (World Bank, United States, 2002) p.107.

[2] Dyck A and Zingales: The Journal of Finance, Vol. 59(2004) No.2, P.537

[3] Dyck, Alexander, and L. Zingales: The Journal of Finance Vol.3 (2008) No.63, p.1093.

[4] Y. Zhang: Economics Information, (2009) No.6, p.55. (In Chinese)

[5] G.P. Li: Journal of Shanghai Lixin University of Commerce, (2008) No.2, p.39. (In Chinese)

[6] Z.P. Yu, G.L. Tian, B.L. Qi and H. Z: Management World, (2010) No.9, p.93. (In Chinese)

[7] P.G. Li, Y.F. Shen: Economic Research Journal, (2010) No.4, p.14. (In Chinese)

[8] W.H. Cuo, P.g. Li: Nankai Business Review, (2012) No.1, p.33. (In Chinese)

[9] L. Geng: Media Observer, (2013) No.7, p.54. (In Chinese)

[10] J.G. He, M.H. Wei and F. Liu: Management World, (2008) No.10, p.141. (In Chinese)

[11]B. Wang, M. Wei and M. Li: East China Economic Management, (2014) No.10, p.142. (In Chinese)

[12]P.G. Li, S.M. Xu: Journal of Financial Research, (2013) No.4, p.196. (In Chinese) 